\title{
An Interpretation of Mrs. Strickland's Tragic Marriage in The Moon and Sixpence from the Perspective of Jungian Archetypal Theory
}

\author{
Yanhui Wang \\ Luoyang Normal University, Luoyang, China \\ Email: mlbsabc@sina.com
}

How to cite this paper: Wang, Y.H. (2017) An Interpretation of Mrs. Strickland's Tragic Marriage in The Moon and Sixpence from the Perspective of Jungian Archetypal Theory. Open Journal of Social Sciences, $\mathbf{5}$, 130-137.

https://doi.org/10.4236/jss.2017.54012

Received: March 2, 2017

Accepted: April 22, 2017

Published: April 25, 2017

Copyright $\odot 2017$ by author and Scientific Research Publishing Inc. This work is licensed under the Creative Commons Attribution International License (CC BY 4.0).

http://creativecommons.org/licenses/by/4.0/

\begin{abstract}
The thesis tries to analyze Mrs. Strickland's marital tragedy in The Moon and Sixpence from the perspective of Jungian archetypal theory. After a careful and thorough study of Mrs. Strickland's four archetypes: anima (animus), persona, shadow and self, it is found that it was Mrs. Strickland's self who was controlled by her persona that led to her failure in marriage.
\end{abstract}

\section{Keywords}

The Moon and Sixpence, Jungian Archetypal Theory, Marital Tragedy

\section{C.G. Jung's Archetypal Theory}

Carl Jung (1875-1961), as a great thinker and an outstanding psychologist, is renowned for his prominent contribution to the revision, development and enrichment of Sigmund Freud's theory. Enlightened by Freud's concept of unconsciousness, Jung proposed in his works that the unconsciousness contains the personal stage which is based on the individual experience and the collective stage, which "rests upon a deeper layer, which does not derive from personal experience and is not a personal acquisition butis inborn" [1]. He further mentioned that the personal unconscious is expressed in all kinds of complexes, but the heart of the collective unconscious are archetypes. In his work Researches into the Phenomenology of Self, Jung mentioned four important archetypes: anima and animus, the persona, the shadow, the self. They are in an order from the outset towards the inner when a person steps into a heterosexual relationship and gradually tries to maintain a relationship.

In Jung's theory, the anima archetype is the feminine side in a man's unconsciousness while the animus archetype is the masculine side in a woman's un- 
consciousness [2].

The persona archetype is a mask he wears to show ourselves to the outside world. He pretends to be someone different from who he really is. To be adapted to the society, it is helpful. But it can be harmful, if one overdevelops his persona and his true nature may get restrained, which situation is called as "inflation" [3].

"The shadow archetype is the dark side of human nature and it contains the basic, primitive animal instincts. It is hidden and suppressed in a person's unconsciousness, made up of "dark" thoughts, which people usually refuses to talk about." [4]. If he is controlled by his shadow, he will be led astray and do bad to people around. If his shadow is entirely pressed, he becomes a good man with a mild character, but chances are that his shadow will revolt.

The self archetype represents the wholeness, integration and harmony of an individual. It functions to organize, harmonize and bring into order all parts of the other archetypes. The self drives people to realize a psychic fullness through the realization of self-hood. The development of the self can help make a proper adjustment in his life so that he could live happily in the world.

\section{Mr. Strickland's Marriage Tragedy}

In The Moon and Sixpence, Mrs. Strickland lived a perfect life in the other people's eyes, since she had a good husband with a mild temper and a decent job in the bank, and two brilliant children. But she was still abandoned by her husband suddenly after a 17-year-long marriage. Such a long marriage with two adorable children should not break up at one night, but it happened to Mrs. Strickland. A variety of reasons might trigger Mrs. Strickland's unfortunate marriage, such as conflicts of their personality, the lack of knowledge of each other and so on. In this paper, the author tries to search for the reasons causing her unhappy marriage according to a study of her archetypes.

\subsection{Conflict with Anima and Animus in Marriage}

Anima and animus are two typical archetypes in Jungian archetypal theory. Anima reflects a man's feminine inclination, often seen as the ideal woman's image in a man's eyes. Animus stands for a woman's masculine inclination, actually a man's image in a woman's eyes [5]. In the following part, the author tries to deal with Mrs. Strickland's animus-her masculine inclinations and the conflicts with her husband's anima-his feminine inclinations in their marriage.

\subsubsection{Mrs. Strickland's Masculine Inclinations}

In The Collective Works of Carl Jung, he mentioned that Masculine inclinations is the male side existing in a female's collective unconsciousness, and that women have formed their animus archetypes through thousands of years of continuous contacts with men [6]. The archetype of animus is always projected by contacting and communicating with men, which will help us find the female's masculine inclinations and detect the problems hidden in their marriage. 
Mrs. Strickland's animus was often projected upon her husband-Mr. Strickland. She fell in love with him and accepted him before he proposed to her. Mr. Strickland held the masculine characteristics of a man's appearance. He was "broad and heavy, with large hands and feet... not good-looking, yet nor ugly, for his features were rather good" [7]. From the projections on her husband, we figured that Mrs. Strickland's animus image was a man with manly appearance, good constitution.

Mrs. Strickland's animus was also showed in her masculine features: independence. It was shown in mainly four aspects. Firstly, she didn't center her life on her husband. On the contrary, she developed her own interest in reading and quite sociable. Secondly, she was rather sophisticated to handle the complicated and subtle social relationships and to make the luncheons and evenings go smoothly. Thirdly, she had the capability and taste in managing her surroundings. "Her flat was always neat and cheerful, gay with flowers, and the chintzes in the drawing-room... were bright and pretty" [8]. Fourthly, she also showed her courage and capability to make a living. After she was abandoned and left almost penniless by her husband, instead of crying and waiting at home, she started to learn type and start business, which was turned out to be a success. "She did little typing herself, but spent her time correcting the work of four girls she employed" [9]. She was also quite creative and efficient. she had the idea of making use of blue and red inks and binding the copy in coarse paper. By doing this, she acquired a reputation for neatness and accuracy. Such creativity and decisiveness were a symbol of independence which were seldom seen in a woman.

\subsubsection{Marriage in Want of Ideal Anima and Animus}

Mrs. Strickland's marriage was on the basis of physical attractions. But when living together, Mr. Strickland was not Mrs. Strickland's ideal animus and Mrs. Strickland could not meet her husband's anima.

In Jung's theory, Jung describes four stages of animus "in a female's unconscious development: Hercules-Alexandria-Apollo-Hermes" [10]. At her Hercules stage, she was fond of a man with a strong body and physical power; at her Alexandria she looks for an independent man who is free of love, women and material bondage; while at her Apollo stage she will love a wise man who could guide her and teach her like a professor or a teacher; at her Hermes stage, she will notice a perfect man filled with inspiration and creation. Every woman has an animus in her mind. She first projects her animus on her father, and then, on her spouse or her lover. Jung also described four stages of anima "in a male's unconscious development: Eva-Helen-Maria-Sabiancia" [11]. At his Eva stage, he looks for a woman who is like a mother; at his Helen stage, he is in want of a sexy partner, enjoying a physical pleasure; at his Maria stage, the man grows to appreciate a wise woman; at his Sabiancia stage, he appreciates a perfect woman, pure and noble.

Mrs. Strickland's animus developed from Hercules stage to Apollo stage. Her ideal animus was reflected in a more sophisticated man, like a "professor" or a 
"teacher", who could help her to develop her interests in art and in social status. While her pursuit made her husband very uncomfortable, he didn't want to grow up to the Apollo stage. For example, he didn't want to shave and neatly dressed and showed no interests in her guests and taste in art. He also didn't want her help and understanding in his pursuit. Eventually, Mrs. Strickland and the family life became a bondage to him. What he looks for from a woman still stays on the Helen stage, which meant he was inclined to pursue physical enjoyment rather than inner part. Mrs. Strickland was a grown woman to the Maria stage, who wanted to support her husband to develop his interest in art and promote his social status. They are so different. It was no wonder if such two persons lived together, their life would be full of conflicts and disharmony. Therefore, lack of ideal man's and woman's image in each other was the essential reason for Mrs. Strickland and Mr. Strickland's unfortunate marriage.

\subsection{Problems Covered by Persona}

The original meaning of persona is "mask" or "veil" [12]. Everyone wears a mask to meet with a certain social situation. Persona will help people adapt to the social standards, but sometimes it could be "overdeveloped and thus restrain our true self, turning people into a person he wouldn't recognize” [13]. In this part, the author will analyze Mrs. Strickland's and her husband's persona separately, and then demonstrate its bad effects to their marriage.

\subsubsection{Mrs. Strickland's Mask of Being Obedient to the Society}

Being obedient to the society was Mrs. Strickland's mask. The social rules in the English society of the $20^{\text {th }}$ century were that men go out to work while women took care of domestic life. The best choice of women was to marry a good and rich man so as to gain a whole life guarantee.

Mrs. Strickland followed such a trend of marrying a good man and being a virtuous wife. She married at the age of 18 to a stockbroker and demonstrated a decent and harmonious life to people during the 17-year-long marriage life. She was also wearing a mask after her husband's escape by deceiving others and herself that she still had a husband and an intact family and kept a room at their home in case her husband returned. After her husband's genius was recognized by the world, she immediately took up the responsibility of being the wife and behaved as if she was quite supportive to her husband's drawing career and always appreciating his gift. In her conversations, she often intentionally omitted the fact that she once worked on her own, for in her eyes it was only really decent for a nice woman to live on other people's money.

\subsubsection{Marital Problems under the Mask}

Under the beautiful masks, the Stricklands went on different ways. Mrs. Strckland came to believe the role she played, she was deceiving herself that the marriage was harmonious and the family life was quite sound. At the same time, people including his wife were deceived by Mr. Strickland's mask. In the marriage, he was a very shy, quiet and dull man, no expert in social activities and no 
talents or interests in arts. His nature and desire for art was oppressed for such a long time,then he began to revolt. In his words, "when a man falls into the water it doesn't matter how he swims, well or badly: he's got to get out or else he'll drown" [14].

Mrs. Strickland's persona developed her into an active and social creature, while Mr. Strickland was introvert and quite silent. Mrs. Strickland echoed the social calls and would like to wear a hypocritical mask all her life, while Mr. Strickland listened to the sound of his heart and finally tore his mask into pieces. Such a different character would surely lead them into separated ways.

\subsection{Marriage Destroyed by Shadow}

"Shadow is the evil, immortal and usually the repressed part of human nature, which people usually refuses to acknowledge. When it is dormant in person, it could be detected through people's exchanges; but when it's over suppressed, it revolts exerting a devastating role in people's life." [15]. In this part, we'll dig out both Mrs. Strickland's and her husband's dark inner sides and the tragic effects in their marriage.

\subsubsection{Mrs. Strickland's Dark Inner Sides}

Callousness was Mrs. Strickland's shadow. When her husband left her for all, what she was sad about most was not her husband's leaving, but the rumors from people around. Besides this, the interest in art and play was not out of her heart, but for the trends she wanted to follow. Meeting with writers was a fashion at that time. She won people's sympathy by means of spreading a rumor herself that her husband was gone with an actress. By doing this, she intentionally covered the fact that her husband was fed up with her and the family life. Mrs. Strickland's persona was so strong that she had lost her true nature, and became an insincere woman.

Thus, shadow began to inflate to the surface. In facing difficulties or disasters, it was out of a basic animal instincts to do contemptible things to protect oneself and to survive in the critical moment. When she learned that her husband left her for art, Mrs. Strickland immediately gave up the hope of getting her husband back claiming “...it's finished. I'm as indifferent to him as if he was a stranger. I should like him to die miserable, poor, and starving, without a friend. I hope he'll not with loathsome disease. I've done with him". She meant what she said. She told people that she wouldn't divorce him and wouldn't set him free to do what he want. She actually didn't care about her husband's life after his leaving.

\subsubsection{Marriage Ruined by Dark Inner Sides}

It was Mrs. Strickland's persona increased her husband's shadow. What Mrs. Strickland was concerned about was the abundant family life, but what Mr. Strickland was looking for was a free life. When he kept silent, it only meant he had no interest in the people whom his wife appreciated and the family life that his wife created. As a result, he left without mercy on his wife and children.

Meanwhile, his shadow helped his wife's shadow to grow. When being told 
the reasons about the husband's leaving, Mrs. Strickland didn't go out and look for the her husband herself. She was afraid of being declined. Love seemed so fragile in front of her persona. For a long time, she still lived under a family with a husband involved. So, it seemed that both of them cared more about themselves, less about the other side. The coldness to each other would surely lead the couple's marriage to go astray.

\subsection{Marital Tragedy by Failed Self-Adjustment}

A person may feel very happy and live harmoniously with people around, and easily adapt to the outside world, if the archetypes stays in a balanced situation under the control of self. A person may feel unhappy and his life may be full of miseries, if the self loses control of other archetypes.

\subsubsection{Frustrated Self-Adjustment in Mrs. Strickland}

Mrs. Strickland's self played a negative role in her development. Herself was controlled by her persona, and lost regulations on the other archetypes. Her animus led Mrs. Strickland to the beginning of her marriage; the inflation of her persona controlled her soul; her shadow worsened her marital conflicts with her husband; at last, the couple went on different ways and lived in separation.

The Stricklands married for their match in their appearance. But when they started the marriage life, Mrs. Strickland showed too much masculine features: capable, independent, sociable and sophisticated, which compared her husband into a silent and an useless figure. Herself failed in reminding her to build up and showing more feminine features facing her husband. For example, She didn't wear a makeup to please her husband, who was a typical man both in character and in appearance. If her "animus" was not enough to ruin a marriage, then the mask she wore put the marriage in danger. The mask made her a hypocritical woman. The vision of owning a perfect life held her so strongly that she did not realize that such a desire of a comfortable life was absolutely not what her husband desired. To protect her persona, Mrs. Strickland hid her shadow secretly in the beginning of their marriage. Since her husband had destroyed her beautiful mask, her shadow surfaced. She finally left her husband alone, even hoping him to die.

\subsubsection{Marriage Tragedy Caused by Failed Self-Adjustment}

The archetypes may not always stay in a balanced situation, for a period of time, "one archetype may be stronger than others and sometimes weaker" [14]. There is no danger if the self is capable enough to keep control of other archetypes. But if one archetype gets so inflated that it restrains the other archetypes, and then the self fails to control it, and then the person will be in a dangerous condition and may properly do something bad to himself or people around.

In the beginning of their marriage, the self could hold balance of the archetypes: Mrs. Strickland's masculine inclinations were still under her husband's endurance; one's particular persona never troubled the other's self-consciousness; and the shadow hid calmly and peacefully under the representation of per- 
sona.

But after a long time rubbing together, the cracks became wider and wider: Mrs. Strickland's animus became a bondage to his husband and her persona kept her too far away from his husband's nature. Mr. Strickland's shadow exploded first, and then he abandoned his mask leaving everything behind him. After that, Mrs. Strickland felt greatly hurt and she, for a while, was controlled by her shadow. But soon herself turned Mrs. Strickland back to her persona. She held tightly of her persona while her husband wanted to throw away his mask and let his shadow go freely. Theirself's incapability of managing their respective archetypes and the extreme inflation of the certain archetype affected the harmony of their life and disintegrated their marriage.

\section{Conclusions}

The thesis tries to dig out Mrs. Strickland's psychological reasons of her marital tragedy by making a careful study on her archetypes.

According to Jungian archetypal theory, Mrs. Strickland in The Moon and Sixpence was a typical woman whose self was controlled by her persona. Mrs. Strickland's persona turned her into a hypocritical woman yearning for material enjoyment, which became an unbearable factor for her husband. So, she was partially responsible for her husband's escape. His escape uncovered her shadow of being a selfish and cruel woman. Her shadow further stimulated her to save her humiliation and protected her persona. Her persona became over-inflated and finally controlled herself. At the same time, Mr. Strickland would not surrender his self to hers. The couple were so faraway from each other that in the end they would not see each other and care for each other. That's why her marriage could not be happy.

Based on the above analysis of Mrs. Strickland's archetypes, the study helps us find the psychological reasons causing her tragic destiny in The Moon and sixpence and thus we could get a better understanding of the book and the writer. Nevertheless, limitations also exist in this paper. For example, the study is mainly focused on the four archetypes in Mrs. Strickland, but other archetypes are omitted. So a further and multi-perspective research should be done in order to have a full and more subjective understanding on women's destiny in this book.

\section{References}

[1] Bressler, C.E. (2000) Literary Criticism: An Introduction to Theory and Practice. Prentice Hall, Inc., Upper Saddle River.

[2] Carol, C. (1996) Wittgenstein Reads Freud: The Myth of the Unconscious. Princeton University Press, Princeton, 25.

[3] Fordham, F. (1987) An Introduction to Jung's Psychology. Penguin Harmondsworth, England.

[4] Jung, C.G. (1963) Memories, Dreams, Reflections. Edited by Jaffe, A., Ed., Translated by Winton, C. and Winton, R., Random House, 121-123.

[5] Jung, C.G. (1968) The Collected Works of C. G. Jung Vol. 9(I): The Archetypes and the Collective Unconscious. Edited by McGuire, W., Translated by Hull, R.F.C., 2nd 
Edition, Princeton University Press, Princeton, 3.

[6] Jung, C.G. (1970) The Collected Works of C. G. Jung Vol. 17: The Development of Personality. Edited by McGuire, W., Translated by Hull, R.F.C., 2nd Edition, Princeton University Press, Princeton, 35.

[7] Jung, C.G. (1971) The Collected Works of C. G. Jung Vol. 6: Psychological Types. Edited by McGuire, W., Translated by Hull, R.F.C., 2nd Edition, Princeton University Press, Princeton, 135.

[8] MacCarthy, D. (1973) William Somerset Maugham: An Appreciation. Harper \& Row, New York, 58-230.

[9] Maugham, W.S. (1943) Maugham's Introduction to Modern English and Literature. The New Home Library, New York, 65.

[10] Maugham, W.S. (1980) The Moon and Sixpence. Pan Books Ltd., London, 279-493.

[11] Neumann, E. (1994) Fear of the Feminine and Other Essays on Feminine Psychology. Princeton University Press, Princeton.

[12] Robin, M. (1980) Conversations with Willie: Recollections of W. Somerset Maugham. Pan Books, London.

[13] Rogal, S.J. (1997) A William Somerset Maugham Encyclopedia. Greenwood Press, London.

[14] Rowland, S. (1999) C. G. Jung and Literary Theory. St. Martin's Press, New York, 13.

[15] Samuels, A. (1985) Jung and the Post-Jungians. Routledge \& Kegan Paul, London, 61-63. https://doi.org/10.4324/9780203359297

\section{Submit or recommend next manuscript to SCIRP and we will provide best service for you:}

Accepting pre-submission inquiries through Email, Facebook, LinkedIn, Twitter, etc. A wide selection of journals (inclusive of 9 subjects, more than 200 journals) Providing 24-hour high-quality service

User-friendly online submission system

Fair and swift peer-review system

Efficient typesetting and proofreading procedure

Display of the result of downloads and visits, as well as the number of cited articles Maximum dissemination of your research work

Submit your manuscript at: http://papersubmission.scirp.org/

Or contact jss@scirp.org 